\title{
PRESENCE, DEVELOPMENT, YIELD EFFECTS AND CONTROL OF LATE SEASON DISEASES OF WHEAT IN CANTERBURY IN 1995/96
}

\author{
M.A. MACE ${ }^{1}$ and M.G. CROMEY ${ }^{2}$ \\ ${ }^{1}$ University of Canterbury, Private Bag 4800, Christchurch \\ ${ }^{2}$ New Zealand Institute for Crop \& Food Research Ltd, \\ Private Bag 4704, Christchurch
}

\begin{abstract}
Four field trials were established in spring wheat crops in midCanterbury in the 1995/96 growing season, to investigate late season diseases of wheat and their control. Two cultivars, Endeavour and Monad, were used. Three treatments (untreated and two fungicide treatments) were applied at three alternative growth stages (flag leaf emerged, ears emerged, and mid-flowering). Flag leaves were collected 10 days after the final spray application and fungal isolations were made. Green leaf area was assessed at regular intervals as flag leaves senesced. Flag leaves and spikes were collected during dough development and the incidence and severity of fungal pathogens were recorded. Plots were harvested and yield components were determined. The fungicides terbuconazole and ICIA5504 delayed senesence of flag leaves and increased yield in all 4 trials. The increases in yield were reflected in the increases in grain weight suggesting that the effect of the delay of senescence was to increase the period of grain fill. Didymella exitialis had no effect on yield in 1995/96 season.
\end{abstract}

Keywords: Didymella exitialis, wheat, flag leaves, yield

\section{INTRODUCTION}

Didymella exitialis (Morini) Müller has been prevalent on flag leaves of wheat in Canterbury for at least the past 8 years (Cromey et al. 1994; Harvey pers. comm.). This fungus was isolated from symptomless green flag leaves during the 1993/94 growing season and pseudothecia were first present in late November and became more common as crops senesced.D. exitialis is a common cause of leaf scorch on wheat and barley in Europe (Punithalingam 1979) and ascospores of the fungus have been implicated in late summer asthma in humans (Allitt 1986). In Switzerland, D. exitialis and Septoria nodorum Mueller were found to be common endophytes in symptomless green wheat leaves (Sieber et al. 1988). The yield losses caused by other late season pathogens such as $S$. nodorum are well documented, whereas the effects of $D$. exitialis are not. One study indicated that yield losses caused by $D$. exitialis could be as high as $15 \%$ (Paul 1983) while another suggested the fungus was a weak pathogen (Ahrens and Schöpfer 1983). Didymella phleina Punith. and Arsvoll, existing as an endophyte in barley cv. Triumph, was implicated in yield reduction (Riesen and Close 1987), and Cooke et al. (1981) found that there was a yield increase obtained after fungicides were applied to aerial plant parts in the absence of disease symptoms or when slight disease was present.

During the 1995/96 growing season the effects of the fungicides terbuconazole and ICIA5504, applied at three different growth stages were studied in four field trials. The development of all diseases was recorded and the effect of late season applications of fungicides on yield and grain quality was examined. 


\section{MATERIALS AND METHODS}

Four field trials were sown in Mid-Canterbury within commercial spring wheat crops at Chertsey (36 plots), Norwood (36 plots), Mitcham (12 plots) and Methven (12 plots). The cultivar Endeavour was grown at Chertsey and Mitcham and Monad was used at the other two trials. Each trial consisted of plots $10 \mathrm{~m} \times 1.5 \mathrm{~m}$. The trials received the same agronomic treatment as the surrounding crops where normal commercial agronomic practice was followed.

Fungicides (187.5 g/ha terbuconazole as Folicur and ICIA5504 at 1 litre product/ha) were applied at growth stages flag leaf emerged, ears emerged and midflowering in the large trials and at full ear emergence in the smaller trials. Each treatment was replicated four times in a complete randomised block design. Fungicides were applied using a compressed air back-pack sprayer with a hand-held boom fitted with Tee-jet nozzles (Spraying Systems Co no. 25 core, D2 discs) applying 300 litres/ha at $300 \mathrm{kPa}$.

Trials were assessed weekly and then every 2 days as crops became senescent. Ten plants/plot at each leaf position were assessed using standard area diagrams (James 1971) for leaf area affected by blotch, stripe rust, powdery mildew and senescence. Three weeks after the flag leaves of each crop had senesced, 10 flag leaves were collected and examined under a stereomicroscope to determine the percentage leaf area covered by fungal pathogens.

Five flag leaves/plot were collected 10 days after the final fungicide application in each trial. Leaves were surface sterilised with $0.6 \%$ sodium hypochlorite and sterile deionised water for $2 \mathrm{~min}$. Leaf pieces were then plated on to potato dextrose agar (Gibco PDA) and cultured at room temperature under near-UV light. Any fungi isolated were subcultured on PDA and identified where possible.

Plots were harvested when ripe. The harvested grain was weighed and the harvest weight was adjusted to $14 \%$ moisture content.

\section{RESULTS}

The 1995/96 growing season was relatively cool but rainfall was variable. Rain in September provided good conditions for spring growth but November to January were relatively dry. All trials except Mitcham were irrigated but signs of water stress were noted in the Mitcham and the Chertsey trials. The harvest was delayed due to rain in early February. Results from each trial are presented in Table 1. Effect of growth stage at fungicide application has been omitted as this was not statistically significant in any of the trials $(\mathrm{P}>0.05)$.

\section{Flag leaf senescence}

In comparsion with the untreated controls, extra days of green leaf were obtained from the application of fungicide sprays $(\mathrm{P}<0.05)$ at all sites. The Mitcham and Methven trials gave similar results with the application of ICIA5504 giving on average 6.25 days of extra green leaf (Table 1 ).

\section{Disease}

There were low disease levels in the trials, mainly powdery mildew (Erysiphe graminis D.C.) and stripe rust (Puccinia striiformis West.). Blotch or leaf scorching was observed very infrequently and pycnidia of $S$. nodorum and the pseudothecia of Didymella were often present in and around the scorch lesions. On the 8.1.96 at the Methven trial, there was more blotch $(\mathrm{P}<0.05)$ on the flag leaves in untreated control plots than in those treated with ICIA5504.

Yield

At Mitcham the fungicide treated plots gave higher yields than the untreated plots (Table 1). The same general trend was observed at Chertsey and Norwood (Table 1). The grain weight also showed the same trend in the Chertsey trial but not in the Norwood trial. There were no differences $(\mathrm{P}<0.05)$ in yield between terbuconazole or ICIA5504 treated plots and the untreated plots in the Methven trial (Table 1).

\section{Plant pathogens on senesced flag leaves}

The proportion of senesced leaf area covered with $D$. exitialis differed significantly between treatments $(\mathrm{P}<0.05)$. Sporulation of $D$. exitialis on terbuconazole treated 
leaves was higher than in the control and ICIA5504 treatments at the Chertsey trial (Table 1). This same general trend was also observed at the Norwood and Methven trials (Table 1).

TABLE 1: Mean incidence and severity of Didymella exitialis, yields, grain weights and days of extra green leaf in wheat plots in four trials to which different fungicide treatments had been applied.

\begin{tabular}{cccccc}
\hline Treatment & $\begin{array}{c}\% \text { leaves } \\
\text { D. exitialis } \\
\text { isolated from }\end{array}$ & $\begin{array}{c}\% \text { of leaf area } \\
\text { with D. exitialis } \\
\text { sporulating }\end{array}$ & $\begin{array}{c}\text { Yield } \\
(\mathrm{t} / \mathrm{ha})\end{array}$ & $\begin{array}{c}\text { Grain } \\
\text { weight } \\
(\mathrm{mg})\end{array}$ & $\begin{array}{c}\text { Days extra } \\
\text { green } \\
\text { leaf }\end{array}$ \\
\hline
\end{tabular}

\section{Chertsey}

control

terbuconazole

ICIA5504

$12.7 \mathrm{~b}$
$13.3 \mathrm{~b}$
0

$1.0 \mathrm{~b}$
$5.8 \mathrm{c}$
$0.2 \mathrm{a}$

$3.6 \mathrm{a}$

$4.2 b$

$27.0 \mathrm{a}$

3.8

$0.2 \mathrm{a}$

$8.3 b$
$9.7 b$
$0 a$

$1.1 \mathrm{~b}$
$1.3 \mathrm{~b}$
$0.3 \mathrm{a}$

4.1

7.3

1.7

0

0

0

10

30

0
$6.1 \mathrm{~b}$
$11.1 \mathrm{c}$
$0.8 \mathrm{a}$

$7.1 \mathrm{a}$

$7.4 \mathrm{~b}$

46.0

$7.3 \mathrm{~b}$

47.0

1.6

2.1

4.0

$\begin{array}{ccc}4.5 & 34.4 \mathrm{a} & - \\ 4.8 & 35.4 \mathrm{~b} & 4.0 \\ 5.1 & 36.4 \mathrm{~b} & 6.5\end{array}$

Methven

terbuconazole

ICIA5504

$\begin{array}{rr}0 & 6.1 \mathrm{~b} \\ 0 & 11.1 \mathrm{c} \\ 0 & 0.8 \mathrm{a}\end{array}$

\section{7}

40.1

$\begin{array}{ll}8 & 42.2\end{array}$

$8.1 \quad 42.3$

Letters indicate difference $(\mathrm{P}<0.05)$ as indicated by Duncan's Multiple range test

\section{DISCUSSION}

The fungicides terbuconazole and ICIA5504 delayed senescence of flag leaves and increased yields in wheat in four field trials in Canterbury in the 1995/96 growing season. Increases in grain weight were responsible for most of the recorded increases in yield, which suggests that the effect of delay in senesecence was to increase the period of grain fill. Similar results were found by Riesen and Close (1987) where foliar application of propiconazole resulted in higher barley yields than for the untreated control. Differences between the two fungicides were detected for the number of extra days of green leaf gained, which suggests that D. exitialis had, at most, a minor influence on flag leaf senesence in these trials.

As was found in previous years, D. exitialis may be cultured readily from untreated symptomless green leaf leaves. This agrees with other results (Ahrens and Schöpfer 1983; Cromeyet al. 1994), and suggests that D. exitialis probably exists endophytically within leaf tissue causing disease symptoms on its hosts only when the conditions are optimal for disease development. The fungus was present in all four trials, and its severity was highest following the application of terbuconazole.

Although the terbuconazole treated plots had greater levels of D. exitialis sporulation, the yields from the two fungicide treatments were similar and higher than the untreated. It is therefore concluded that $D$. exitialis had no effect on yield under the prevailing weather conditions this season. As leaf scorch was not common in these trials, it is possible that $D$. exitialis may affect yield under conditions that are highly conducive to disease development. Further work is required to determine the effects of D. exitialis on yield losses in Canterbury under different seasonal conditions. 


\section{ACKNOWLEDGEMENTS}

We would like to thank Messers Ross Hanson (Crop \& Food Research), Ross Bowman (Hodder and Tolley) and Bruce Garrett (Wrightsons Seeds) for sowing and harvesting trials and Messers J. Mulholland, S. Goodwin, R. Irwin and E. and G. Bassett for providing land and agronomic management for the trials. This research was funded in part by the New Zealand Foundation for Research Science and Technology and by a grant from the Foundation for Arable Research.

\section{REFERENCES}

Ahrens, W. and Schöpfer, M., 1983. Schadauftreten des Ascochyta-form vonDidymella exitialis an getreide. Mededelingen van de Faculteit landbouwwetenschappen Rijsuniversiteit Gent.48: 713-722 (cited in the CAB Abstracts 1984).

Allit, U., 1986. Identity of airborne hyaline, one septate ascospores and their relation to inhalant allergy. Trans. Brit. Mycol. Soc. 87:147-154.

Cromey, M.G., Ganev, S., Braithwaite, M. and Boddington, H.J., 1994. Didymella exitialis on wheat in New Zealand. N.Z. J. Crop Hort. Sci. 22:139-144.

Cooke, R.J., Jenkins, J.E.E., King, J.E., 1981. The deployment of fungicides in cereals. Pp 91-99. In: Strategies for the Control of Fungicides in Cereal Disease, J.F. Jenkyn and R.T. Plumb (Eds); Blackwell Scientific Publications, Oxford.

James, W.C., 1971. An illustrated series of assessment keys for plant diseases, their preparation and usage. Can. Pl. Dis. Sur 51:39-65

Paul, V.H., 1983. Felduntersuchungen zur resistenz des winterweizens gegenuber Ascochyta (Didymella exitialis) Medelingen van de Faculteit Landbouwwetenschappen Rijksuniversiteit Gent 48:755-759 (cited in the CAB Abstracts 1984).

Punithalingam, E., 1979. Didymella exitialis. CMI Descriptions of Pathogenic Fungi and Bacteria No. 633. Surrey: CAB.

Riesen, T.K., 1987. Didymella phleina Punith. and Årsvoll endophytic in barley leaves in New Zealand. N.Z. J. Bot. 25: 271-274.

Riesen, T.K. and Close, R.C., 1987. Endophytic fungi in propiconazole-treated and untreated barley leaves. Mycologia 79: 546-552.

Sieber, T., Riesen, T.K., Müller, E. and Fried, P.M., 1988. Endophytic fungi in four winter wheat cultivars (Triticum aestivum L.) differing in resistance against Stagonospora nodorum (Berk.) Cast. and Germ. = Septoria nodorum (Berk.) Berk. J. Phytopath. 122: 289-306. 